ACTA UNIVERSITATIS LODZIENSIS

FOLIA LITTERARIA POLONICA 2(40) 2017

http://dx.doi.org/10.18778/1505-9057.40.04

Paweł Kaczmarski*

\title{
Adam Ważyk, the New Sentence and the question of entropy ${ }^{1}$
}

Why does it matter that a poem be organised in any particular way?

This ostensibly simply question - to which the simplest answer would probably be: because that's how we're able to recognize it as a poem - becomes surprisingly tricky once we realise that it might just be the key to the work of Adam Ważyk: one of the most versatile, pioneering avant-garde authors in the history of Polish literature; an ever-underappreciated expert in poetics and versology whose thoughts on progressive politics and the poetic form remain among the hidden gems of the modern Polish literary criticism.

The issue of the poem's organisation, its fundamental role and function, was central to many of Ważyk's most influential works; but we will find its most explicit articulation in his thoughts on entropy:

Back when Amphion raised his mythical walls, in the era of oral culture, the poem's organization was what prevented the message from being forgotten or eroded; it suppressed the destructive power of time. In the age of print this mnemonic function has been greatly reduced, yet the poem has preserved its durability - meaning that it's still very capable of resisting any attempt to recode it. It cannot be faithfully retold, or reconstructed, without losing an important - perhaps the most important - part of itself.

Information has a tendency to diminish, disperse itself. A recipient may receive less information than the amount he was sent, but he can never receive more. The loss of information corresponds to the increase in entropy. The poem's organization, first convened for the sole purpose of delaying this process, does in fact submit to it as well. [...]

* University of Wrocław, Faculty of Philology, Institute of Polish Studies; pl. Nankiera 15, 50-140 Wrocław; pawel.kaczmarski@przerzutnia.pl.

${ }^{1}$ Tekst powstał w ramach pracy nad projektem grantowym "Nauka chodzenia". Świadomość późnonowoczesna $w$ metapoetyckich wypowiedziach przedstawicieli polskiej neoawangardy lat 60. i 70. XX wieku (11H 130651 82) 0064/NPRH3/H11/82/2014. 
The scholars are not typical readers. Their task is to explain and analyze the structure of the poem, thus compensating for the loss of information; they're supposed to present the message in its yet-unspoiled state 2 .

In the context of Ważyk's work, the relationship between entropy and literature remains something of a focal point, a moment of particular importance and interest ${ }^{3}$; it brings together many of the poet's key intuitions, ideas and insights. An attentive reader may try and analyze it in order to better understand the organizing principles behind Ważyk's own work; and, as we shall see later on, it is precisely here that Ważyk finds a sort of an intellectual and spiritual connection to some of the most important debates of the 20th-century literary Left - including some of the conversations that gave birth to the so-called Language movement.

Perhaps the most obvious, essentially biographical reading of Ważyk's thoughts on entropy would see them as a veiled attempt to retroactively explain and justify the author's own involvement in the political enterprise usually known as the "actually existing" socialism. If by the late 50's Ważyk was indeed disappointed by the Eastern European socialist project, if he could only remember it with a sense of bitterness and failed hopes, then the universal idea of entropy allowed him to blame the failure of this particular project on the inexorable laws of nature rather than any contingent or fundamental flaws within the socialist project itself. It's not the actually existing socialism that brought its own doom upon itself; no specific actions of any particular political actors are enough to convincingly and fully explain its sins and failures. In the end, entropy is to blame - every political project, every human effort and enterprise is bound to eventually collapse under its own weight, descending into chaos; it couldn't have been any different with the socialist project. Ultimately, the socialists' only fault was that they hadn't properly recognized this issue.

Another possible reading: the concept of entropy allows Ważyk to explain the civilizational downfall of poetry itself - that is, the reason for the constant diminishing of its popularity and social influence (a process that stands in stark contrast to some of the avant-garde's most important historical analyses and predictions). Whether the post-war poetry really had no performative potential - and if so, whether it had had it before - is less important than Ważyk's own sense of failed hopes; the feeling that the avant-garde left some of its most important

\footnotetext{
${ }^{2}$ A. Ważyk, Amfion. Rozważania nad wierszem polskim, Czytelnik, Warszawa 1983, pp. 46-47.

${ }^{3}$ For a slightly different version of the same comment, see: A. Ważyk, Esej o wierszu, Czytelnik, Warszawa 1964, pp. 23-24.
} 
promises unfulfilled. This feeling returns almost every time the poet comments on the condition of the contemporary reader and readership. But if literature in general submits to the universal laws of entropy, then the poetry's reduced social influence cannot, once again, be blamed on any specific actions of any particular actors or authors; after all, its failure is not its own.

Yet another possible reading could see Ważyk's understanding of entropy - and especially the idea that literature can somehow delay entropy or tame it - as a trace of the poet's Jewish roots or his peculiarly esoteric spirituality. The shattering of the material reality, its descent into chaos, is inevitable; but it can be slowed down, made more bearable by a conscious human effort. We can't stop the universal downfall, but we can slightly change its direction or pace by finding the moments or points of possible deviation.

Finally, we could read Ważyk's thoughts on entropy in a more secular context, as a part of his reflection on the role of science in the modern democratic society. Ważyk seems to inverse the way we usually think about science: its social function is not to introduce order, but to show the chaos beneath what we might initially perceive as order $^{4}$; for Ważyk, entropy explains that the world we live in has been built through a series of essentially random events. Randomness or chance (and here Ważyk draws heavily from the surrealist heritage) remains the foundation of all human language and communication; and so, indirectly - of all our experience ${ }^{5}$.

Obviously, Ważyk's thoughts on entropy were bound to affect his writings on philosophy and literary theory. His understanding of entropy seems to lead him to an intentionalist attitude of sorts: it suggests that every text/speech act always has a certain objective meaning (a defined quantum of sense) that the reader may then discover or receive (rather than shape or co-produce). Indeed, according to Ważyk, meaning can never be fully known, but it nevertheless exists, and the part that's lost cannot be "filled in" by a creative reader. To slow down entropy, to reduce its terrible influence on all text and language, we can't just embrace the idea of reader as a meaning-producer; we should instead focus on the relatively traditional notion of the poem's formal organization ("The poem's organization, first convened for the sole purpose of delaying this process..."). And although some may see Ważyk as a spiritual cousin to Derrida or de Man - with his idea of meaning being always only partially known, never revealed in full - still, the

\footnotetext{
${ }^{4}$ See Esej o wierszu, p. 27 (here Ważyk writes, for instance, among other issues, about chance as a cause of the seasons).

${ }^{5}$ For Ważyk's thoughts on chance as the foundation of all language (and, consequently, all our being-in-language), see: A. Ważyk, Obnażenie przypadku, “Teksty. Teoria literatury, krytyka, interpretacja” 1973, nr 3 (9), pp. 42-51. Jerzy Święch wrote extensively about Ważyk's attitude towards randomness/luck/chance in the context of his role as the main proponent of surrealism in the Polish poetry. See: J. Święch, Ważyk metafizyczny?, "Ruch Literacki” 2013, z. 1 (316), pp. 35-47.
} 
very assumption of a certain objective "fullness" or "completeness" of meaning is definitely not deconstructionist in nature.

This type of reading, focused on the questions of meaning and intention, seems especially productive; throughout his work, Ważyk made some surprisingly insightful comments about the future of humanities and literary studies in the West (for instance, he managed to predict the rise of interest in academic and literary anthropology, or the main tenets of the so-called cultural $\left.\operatorname{turn}^{6}\right)$. Still, it's important to remember that virtually all of Ważyk's theoretical writings were supposed to have very practical consequences. His comments on versology, poetics and literary history were always written for and by someone whose ultimate interest was the practice of poem-writing. Ważyk considered himself to be, first and foremost, a practicing poet. And so, his near-obsession with the concept of entropy was supposed to have some practical impact as well.

Ważyk's peculiar brand of conscious scientism did not stem from the mere fascination with a scientific „method”. It was instead reinforced by a belief he seems to have shared with Stanislaw Brzozowski, namely - that the very recognition of a natural process, or a law of nature, can in and of itself help tame the said process. Through systemic reflection, by forging new terms, categories and theories, we are able to humanize the non-human and reduce its impact on us. And so, by acknowledging the ultimately destructive power of entropy, one is already slowing it down; the act of naming, or humanizing this seemingly insurmountable natural force is crucial. This is the practical side of the whole issue. As soon as we recognize entropy's impact on our everyday lives, on our language and literature, we are able to truly appreciate the role of poetic form. The poets are now able to write in such a way as to reduce the loss of information, and the readers - aware that this loss is a constant danger - are bound to pay more attention to the formal organization of any given poem.

Thus, to give entropy a name is to tame it - at least to some degree. This idea can obviously be reversed: if entropy could not be tamed - changed in its velocity or direction - then theorizing about it would be largely pointless (at least in the context of poetic practice).

This does not mean, however, that entropy can ever be tamed fully, that it can be slowed down to a complete stop; and the performative power of literary forms does not imply the existence of an imagined formal structure that could

\footnotetext{
${ }^{6}$ For more precise description of Ważyk's vision of the future of humanities, see for instance Marta's Koronkiewicz doctoral dissertation The Poetics of the Everyday (dissertation presented to the Faculty of Philology, University of Wrocław, July 2016).
} 
constantly and completely prevent the loss of information. Even if, hypothetically, some perfect storm of formal figures and devices, contexts and knowledge could cause the reader to remember all that there is to remember - to simultaneously focus on every significant part of a textual structure - some information will always already have been lost. The entropy's impact can be reduced, but never abolished altogether; and so, those who ignore the issue of universal downfall are as naive as those who believe it can be stopped. That's why there's no point in thoughtlessly "forcing" new formal structures and devices into a poem, in some ill-advised attempt to overwhelm the forces of entropy with the sheer power of numbers. "More" form does not necessarily make the poem any "better". At the end of the day, Ważyk was a staunch defender of the avant-garde movement and heritage - and some of his criticisms of both Skamander and Młoda Polska were rooted specifically in what he saw as an ultimately superficial show of rhetorical skill?. Even Ważyk's attacks on Peiper, one of the fathers of the Polish avant-garde literature, were partly founded on what Ważyk considered to be an abundance of formal techniques, an overt focus on formal mastery that had to eventually result in an overwhelming feeling of "artificiality" on the part of the reader".

And so, although the formal organization of the poem was a key issue for Ważyk - and although he devoted many of his metapoetic writings to the history of the Western literary form(s) - he nevertheless never offered a simple, binary solution: organization - good, chaos - bad, or vice versa. At the end of the day, the framework that attracted him most was that of a free-verse poem. In this case, however, "free" did not mean an unconditional liberation from all the old conventions and literary norms; according to Ważyk, the peculiar nature of free verse stems from the tension between organization and chaos - freedom from convention and planned constraint. After all, free verse has its own formal structures and devices; and it was these structures and devices, rather than the idea of "freedom" itself, that Ważyk took particular interest in. As he points out in Amfion, in Poland the emancipatory novelty of the free-verse poem was generally accompanied by the poets' tendency to self-impose a certain set of rules and formal rigours, aimed at combating the influence of the allegedly empty and superficial language of the "Młoda Polska" poetry ${ }^{9}$; and it was on these grounds that Ważyk defended free verse against the accusation of a certain formal sloppiness on the part of "traditionalists"10.

Free verse brings change and liberation, but it also projects a retrospective utopia of sorts; it tells a story about what poetry looked like before it could even be thought of as poetry ${ }^{11}$. First and foremost, though, it offers a certain framework.

\footnotetext{
${ }^{7}$ See A. Ważyk, Eseje literackie, Państwowy Instytut Wydawniczy, Warszawa 1982, p. 59.

${ }^{8}$ See ibidem, p. 61.

${ }^{9}$ See Amfion, p. 39.

${ }^{10}$ See Esej o wierszu, p. 16.

${ }^{11}$ Ibidem, p. 107.
} 
The prospect of change offered by the free verse is based on knowledge and planning, on systemic reflection and poetic insight; it is, above all, a well-organized project, and the opportunity it brings is well thought out. And so, the free-verse poem stands in opposition both to the more traditional, formally conservative (and thus predictable) poetry, and to what Ważyk called anti-poems: poetry obsessed with shock value, poems that rely on tricks for tricks' sake, "dadaist experiments turned rote" 12 . Naive obsession with poetic freedom leads, according to Ważyk, to poems that are nothing more than "fluctuations of the void"13. As Marta Koronkiewicz rightly notes, "[for Ważyk] the loosening of the habitual connections was never supposed to lead to total freedom, quite the contrary: it was a method of giving concrete shape to the formless, the amorphous"14.

As it is usual with such complex and ambiguous structures, the key is thus not in finding the "right" solution - the ultimate answer - but in appreciating the tension itself, the constant movement of the free-verse poem: between stability and instability, change and tradition, liberation and convention. This tension, this dynamic, is the drive behind much of Ważyk's metapoetic thought.

One doesn't need to look far to find proofs of Ważyk's attachment to the notions of tradition and continuity. His search for specifically Polish poetic forms and his in-depth discussion of Mickiewicz's formal achievements are complemented by more theoretical writings on the genesesis and the historical development of the notion of poetry ${ }^{15}$. Ważyk's way of referencing complex poetological concepts is almost casual; he's able to make incredibly precise ad hoc analyses of a poem's rhythmic structure ${ }^{16}$, and his versological knowledge informs even some of his memoir-style writings. From a certain point of view, his approach to the poetic craft may even seem a bit old-fashioned.

And yet, Ważyk very often deploys his vast poetological and versological knowledge to recognize and appreciate various experimental strategies, formal innovations and acts of conscious rejection of the literary traditions and authorities; his sympathies ultimately lie with the avant-garde. And so, he values enjambment as an agent of dissent and productive uneasiness ${ }^{17}$; and throughout his work he remains faithful to juxtaposition, understood not only as a particular device or figure, but as a more general rule of poetic innovation. Juxtaposition's main

12 A. Ważyk, Gra i doświadczenie, in: Eseje literackie, Warszawa 1982, p. 260.

${ }^{13}$ Esej o wierszu, p. 128.

${ }^{14}$ M. Koronkiewicz, p. 171.

${ }^{15}$ Esej o wierszu, a short book from 1964, is the perfect example of Ważyk's ability to combine those two modes of writing: in the first chapter, he reflects upon the ways in which poetry historically participated in shaping the very notion of time; only to pass smoothly on to some very detailed discussion about the role of the poetic pause, about 5 pages into the second chapter.

${ }^{16}$ For one of the most canonical examples, see Ważyk's incredibly detailed comparisons of the rhythmic structure and the role of caesura in Mickiewicz and Kochanowski (Esej o wierszu,pp. 39-41).

${ }^{17}$ See Esej o wierszu, p. 19. 
function - to break and transform the habitual connections, to force readers and authors alike to reevaluate some of their deepest beliefs - is closely linked to the fundamental social and aesthetic tasks of poetry in general ${ }^{18}$.

Thus the concept of entropy, this process of universal change, leads Ważyk to consciously appreciate poetic form and tradition; and this, in turn, leads him back to the question of change and innovation. There's no use in stability without moments of radical change, and no change is possible without some stable points of reference. The art of poetic innovation is to try and reconcile those two polarities in an uneasy alliance.

In the last paragraphs of Gra $i$ doświadczenie, Ważyk sketches out a powerful vision for the neo- or post-avant-garde Polish poetry. In essence, it has to choose between the path of Whitman and the path of Blake ${ }^{19}$. Whitman is the father of the democratic free-verse poem; but for all its freedom, his poetry is well-organised - it's wise, it's self-aware, it's well thought out - and above all, it has a specific purpose (both politically and aesthetically speaking). Blake, on the other hand, is a ,hippie” who, instead of using the poetic form, tries to ignore or circumvent it altogether; he creates visions for visions' sake, and eagerly breaks with tradition just to make some short-sighted tricks. Whitman's approach is, of course, infinitely closer to Ważyk's own.

Ważyk's comments on entropy, poetic form and free verse are partly theoretical, partly political, and partly, perhaps, even cosmological. His key concepts seem to operate on all those levels at once; entropy occurs in every domain of human experience, in every domain it needs to be fought and tamed, and yet in none can it be stopped completely. Chaos and dissent bring liberation and emancipation, while liberation always brings chaos and dissent; those who truly desire change must break with the known forms and conventions, yet they cannot achieve change without specific forms and formal operations. Thus every force, every phenomenon, every key concept seems to be not only linked to all the others, but inherently ambiguous and double-edged.

$$
* \quad * \quad *
$$

The tension between tradition and convention on the one side, and the idea of change through innovation on the other, is an organizing dynamic behind much of the $20^{\text {th }}$ century Marxist ("radical", "revolutionary") literary theory. From

\footnotetext{
${ }^{18}$ A. Ważyk, Dziwna historia awangardy, Czytelnik, Warszawa 1976, p. 78 ff.

${ }^{19}$ A. Ważyk, Gra i doświadczenie, p. 261.
} 
Trotsky reminding his followers that what separates communists from futurists is the formers' familiarity with their own "revolutionary tradition" ${ }^{20}$, through the well-known attempts to reconcile Marxism and formalism ${ }^{21}$, or the coming together of tradition and innovation in Brecht's epic theatre, to the countless turns and shifts within the work of Terry Eagleton - who came a long way from being one of the chief proponents of cultural theory to being an avowed defender of a more traditionally academic approach to literature ${ }^{22}$ - Marxist literary studies have long discussed how to reconcile the desire for innovation with the common-sense intuition that no formal innovation is by default socially progressive, that they all need to be given a certain political direction, lest they turn into tools of the ruling cultural ,elites” and become a means of reinforcing the status quo.

Ważyk's thoughts on entropy, juxtaposition and free verse reflect the same dilemma, the same tension. On the one hand - there's the concept of entropy as something ultimately unstoppable, the importance of juxtaposition, the idea of poetry as a challenge to our habits and assumptions; on the other hand - there's the respect for tradition and continuity, the significance of form and poetic organization, the need to tame entropy. When Ważyk accused those willing to follow Blake - this "completely insane ${ }^{23}$ " poet - of empty tricks and shallow visions, of "hippism", he implicitly (and probably unconsciously) referred to the debate taking place among his Marxist colleagues in the West. Here we see Ważyk, a progressive socialist poet, defending the idea of a planned, organized, purposeful change represented by Whitman, and condemning the trigger-happy, thrillseeking, Blake-loving "hippies". One wouldn't be wrong to link these intuitions to some of the debates that shaped the New Left (think primitive anarchists / hippies versus socialist organisations and the more traditional party structures) or the left wing of the counter-culture movement ${ }^{24}$.

What I'd like to propose, however, is that we read Ważyk's thoughts on entropy and free verse in the context of a very particular discussion that took place

${ }^{20}$ See Futurism, in: L. Trotsky, Literature and Revolution, trans. R. Strunsky, https://www. marxists.org/archive/trotsky/1924/lit_revo/ [accessed on 15.12.2017].

${ }^{21}$ See T. Bennett, Formalism and Marxism, Methuen, London 1979.

${ }^{22}$ I refer, of course, to the shift that resulted in such books as After Theory (London 2003), where Eagleton rescinded some of his key "theoretical" beliefs, and The Event of Literature (Yale 2012).

${ }^{23}$ Gra i doświadczenie, p. 261.

24 The image of the counter-culture movement as constituted by two wings of factions, united in action but extremely different in their approach to organization, institution and discipline, has been historically reinforced not only through the academic analyses of the movement, but the literary description as well. For a canonical example, one could refer to a scene in "The Sixties" by Jenni Diski, when a group of young German socialists (led by Rudi Dutschke) joins a march of British students and tries to impose their own "strict" organizational approach on all participants. 
among certain progressive and neo-avant-garde authors in the US in the late 80s/ early 90s. Specifically, I refer here to the debate that started with Ron Silliman's The New Sentence, and that was then taken up (and made more explicitly political) by Fredrick Jameson and Bob Perelman ${ }^{25}$.

Let us very briefly summarize the main points of the debate. In his famous essay, Silliman offered a historically and theoretically informed definition of what he called the New Sentence, that is, a certain mode (or a style, or a method) of writing that focused on the sentence as the main unit of language, and that was supposedly created and developed by some of the Bay Area poets. The New Sentence writing combined prose and poetry; among its harbingers was Gertrude Stein (Silliman specifically references Tender Buttons); and its primary social and aesthetic function was the rejection of the petrified, conventional narrative structures in favour of the highly contextualized and purposefully obscure intersentence connections, which linked together the seemingly autonomous sentencelike fragments. This rejection was supposed to reveal the hidden structures and narrative orders within the text, its "hidden capacities":

Nonetheless, any attempt to explicate the work as a whole according to some "higher order" of meaning, such as narrative or character, is doomed to sophistry, if not overt incoherence. The new sentence is a decidedly contextual object. Its effects occur as much between, as within, sentences. Thus it reveals that the blank space, between words or sentences, is much more than the 27th letter of the alphabet. It is beginning to explore and articulate just what those hidden capacities might be ${ }^{26}$.

In other words, the New Sentence starts with the sense of dispersion, isolation and confusion, and then pushes to look for some deeper unclear connections that up to this point had been obscured by the traditional forms, conventions and habits. This approach to literature and writing was to define in the upcoming years the whole of the Language movement; Silliman's essay became one of the movement's unofficial manifestos ${ }^{27}$.

This poetic theory has been the object of staunch criticism formulated by Frederic Jameson in one of the chapters in his Postmodernism. According to Jameson, The New Sentence and the Language poetry as such, personified here

${ }^{25}$ See R. Silliman, The New Sentence, in: The New Sentence, Roof Books, New York 2003, pp. 63-93 (first published in 1987); F. Jameson, Postmodernism, or, the Cultural Logic of Late Capitalism, Verso, London-New York 1992 (first published 1991); B. Perelman, Parataxis and Narrative: the New Sentence in Theory and Practice, "American Literature", Vol. 65, No. 2 (Jun., 1993), pp. 313-324.

${ }^{26}$ R. Silliman, The New Sentence, p. 92.

${ }^{27}$ Regarding the importance of Silliman's essay, see M. Perloff, Avant-Garde Community and the Individual Talent, http://marjorieperloff.com/essays/avant-garde-community-and-the-individual-talent/, [accessed on: 15.12.2017]. 
by Bob Perelman, supposedly "adopted schizophrenic fragmentation as their fundamental aesthetic" 28 ; they were proof positive that the

schizophrenic disjunction [...] when it becomes generalized as a cultural style, ceases to entertain a necessary relationship to the morbid content we associate with terms like schizophrenia and becomes available for more joyous intensities, for precisely that euphoria which we saw displacing the older affects of anxiety and alienation ${ }^{29}$.

In other words, the styles developed by the Language poets are here identified as precisely among the forces or processes that unwittingly reinforce postmodernism as the logic of late capitalism.

In his defense of the New Sentence, Perelman decided to emphasize the political elements of Silliman's essay, and to push the whole concept into a more openly Marxist territory. Perelman saw the focus on parataxis as the most important feature of the New Sentence, and the source of its progressive potential; but parataxis was to be understood broadly, as a general rule or formal framework rather than just a specific device (quite similarly to Ważyk's juxtaposition).

The new sentence is a term coined by Ron Silliman to describe certain prose works by various language writers, including himself, in the late seventies and early eighties. To simplify his wide-ranging discussion, a new sentence is more or less ordinary itself but gains its effect by being placed next to another sentence to which it has tangential relevance. New sentences are not subordinated to a larger narrative frame nor are they thrown together at random. Parataxis is crucial: the internal, autonomous meaning of a new sentence is heightened, questioned, and changed by the degree of separation or connection that the reader perceives with regard to the surrounding sentences ${ }^{30}$.

Where Jameson saw the Language poets surrender to the postmodern processes of fragmentation, Perelman saw the opportunity to reclaim it for progressive purposes. For both Silliman and Perelman, the New Sentence was built on the vision of the fragmented, anomic, alienated world, but ultimately sought to subvert it through the literary form ${ }^{31}$.

First and foremost, however, Perelman emphasized the role of parataxis as a force that simultaneously de- and re-narrativises the text. According to him, the radical break with the conventional, habitual narrative connections and conventions was in and of itself progressive and productive: "By keeping free from ficti-

${ }^{28}$ Jameson, Postmodernism, p. 28.

${ }^{29}$ Ibidem, p. 29.

${ }^{30}$ B. Perelman, Parataxis and Narrative, p. 313.

${ }^{31}$ Perelman saw a realisation of this concept in Siliman's own Ketjak and Tjanting, but the question of the relationship between theory and practice in the New Sentence writing, although fascinating, remains beyond the scope of this essay. 
tious totalization, each new sentence represents an enclave of unalienated social work. Where Jameson sees signifying chains snapping, Silliman sees the cobwebs of the reified narratives of false consciousness being swept away"32.

But if the New Sentence could be reduced to this narrow understanding of parataxis, at some point it could also be - in accordance with Jameson's intuitions - easily recuperated and coopted by the ideological narratives of late capitalism. Only when complemented by the work of re-narrativisation - an implicit suggestion that those seemingly autonomous fragments do eventually come together into a less transparent, more intricate order - can parataxis truly resist the reactionary narrative(s). It does more than just reject the simplicity of obvious totalities - it points out the hidden complex ones. Parataxis exposes the ideological mechanisms and devices at work in places we tend to ignore in the course of our daily lives. Far from being an act of dissolution for dissolution's sake or a simple surrender to the forces of chaos, parataxis is in fact a form of complex rebellion. Its extensive use by the Language poets stems from a twofold observation. First, the dominant, hegemonic vision of the world has already permeated our collective consciousness with the ideas of fragmentation and isolation. Second, it's only through conscious, purposeful operations on the already-fragmented language that we can truly overcome this hegemonic vision. One cannot simply ignore the chaos and randomness that are already there; one can, however - at least for a moment, at least for the duration of a poem - tame them or go beyond them, in an attempt to expose their hidden dynamic:

Jameson and Silliman both make wide theoretical claims; both are trying to fight reified parataxis-commodification with a more committed, critical parataxis-the finding of hidden categorical similarities. Denarrativization is a necessary part of the construction of these wider paratactic arguments. But in both cases this process needs to be seen for the combined reading and writing practice that it is: renarrativization is also necessary. If we try to separate out the results of these practices, we are left with fictions, metaphorical condensations, reifications: the purely autonomous new sentence on the one hand, and the rubble of snapped signifying chains on the other ${ }^{33}$.

Let us now return to Ważyk. As should be quite clear by now, the argument between Jameson and Perelman is ultimately built on the same tension that organized much of Ważyk's work. Parataxis - now understood not only as a specific device, a poetic technique, but a more fundamental formal framework or a general rule - has a function similar to that of Ważyk's juxtaposition (and, to

\footnotetext{
32 B. Perelman, Parataxis and Narrative, p. 317.

${ }^{33}$ Ibidem, p. 323.
} 
a smaller degree, enjambment). It's a figure of constant movement and productive dissent which abolishes the old habits. More than that, however, it allows us to bend entropy to a specific purpose, change its direction in accordance with some of our human needs and experiences. Ultimately, then, parataxis is the process of fragmentation harnessed and reclaimed for the purposes of the critique of ideology. This is where Silliman's and Perelman's perspective differs from Jameson's:

Contrary to Jameson's analysis of the new sentence, [Silliman's] writing seems to me self-critical, ambitiously contextualized, and narrative in a number of ways. Far from being fragments, these sentences derive from a coherent, wide-ranging political analysis, one that is quite similar to Jameson's; it is far less nuanced philosophically, but inasmuch as it factors in its own writing practice, it is in fact wider. Many sentences are themselves brief narratives, but more important is the overall frame Silliman shares with Jameson: the marxist master-narrative that sees reification not as stable reality but as a necessary stage of history. This master-narrative links these sentences: the domesticity of the kitchen with the spectacle of identical bungalows with the minute units of the pennies in the fountain with the small verbal differences between sentences that Quine ignores; the renter with the homeowners with the homeless person; housing policies with positivism with writing practices. Silliman's sense of the broken integers produced by capitalism is inseparable from his commitment to the emergence of a transformed, materialist society ${ }^{34}$.

Jameson was afraid that, at least in the case of the Language poets, loosening of the conventional syntactic connections would become an empty formal trick, a superficial game, that it would lead to anarchy for anarchy's sake, the fetishisation of chaos as such, which, in turn, would only serve to reinforce the foundation of the postmodern world, already rooted firmly in the "schizophrenic fragmentation" and various hidden processes of alienation. But what Perelman saw in the new textual opening offered by the paratactic writing was a subversive transformation of those very processes. Parataxis did not abolish order as such; it redirected the reader's focus from the most obvious narratives to the hidden ideological structures by reinventing the roles of both the reader and the author. Denarrativisation was always accompanied by renarrativisation, and their constant interplay reflected the tension between entropy and form that we already observed in some of Adam Ważyk's writings.

This is not to say that within the framework of the New Sentence parataxis played the exact same role as Ważyk's "form" or "poetic organisation" - that is, to combat the influence of entropy; rather than that, we should see the whole issue in terms of a structural similarity, with the relationship between paratactic

\footnotetext{
${ }^{34}$ Ibidem, p. 318.
} 
denarrativisation and renarrativisation running parallel to the constant interplay of form and entropy.

From this point on, the integrity of the literary work, the sense of "whole" and the narrative structure itself were supposed to be based on a foundation stronger than the reader's old habits and obvious conventions. They needed to stem directly from the specific issues raised each time anew by the author herself, the questions about specific linguistic automatisms, specific rules and forces at work behind any given version of reality. Speaking about juxtaposition and the historical role of the avant-garde, Ważyk observes: "The reduction of habitual connections led to the image of the world becoming fragmented, broken into pieces brought together like a mosaic. The world that emerged allowed for the seeping of the pieces of memories, dreams, visions drawn from our deepest imagination. [...] The bringing together of the whole vision by the artist was a question that had to be posed each time anew, a question of the poetic insight and the internal culture of every author" 35 . Clearly, Perelman would subscribe to these claims wholeheartedly. To provide a different example, here is Ważyk speaking about the cinematic montage:

The technique that the film industry calls montage, the collation of images, coincided with my personal tendency to see the main source of value, the main source of all poetic emotion, in juxtaposition. To paraphrase Horace's famous statement about the words that should surprise each other, I could say that for me, personally, poetry consisted of sentences that surprised each other. Sentences, images, events ${ }^{36}$.

The idea of sentences "surprising" one another could just as well describe the nuanced and unobvious narrative structure of the New Sentence writing.

$$
* \quad * \quad *
$$

Adam Ważyk was able to intuitively, yet precisely grasp and describe a certain imagined tension that to this day remains crucial to the modern progressive and radical debate on the role of formal innovation in literature. This tension, as we have already seen, has appeared in many places and traditions throughout history; and it links the poet to a certain progressive, radical tradition. I have tried to illustrate, how this vert tension comes to the fore in certain key aesthetic debates that shaped the American poetic scene at the end of the previous century.

Those who study Ważyk's work, especially his metapoetic writings, are always tempted to read them in the context of his French inspirations, particularly

\footnotetext{
${ }^{35}$ A. Ważyk, Dziwna historia awangardy, p. 80.

${ }^{36}$ A. Ważyk, Kwestia gustu, in: Eseje literackie, pp. 59-60.
} 
Ważyk's fascination with surrealism and Apollinaire. And although these sources of influence obviously cannot be ignored, it seems important to remember that Ważyk's intuitions about the nature of the whole avant-garde movement quite often went beyond any single idea or a particular group of authors; and concepts such as entropy, juxtaposition or the "habitual connection" link Ważyk to a much broader political and aesthetic tradition.

\section{Bibliography}

Bennett Tony, Formalism and Marxism, Methuen, London 1979.

Jameson Fredric, Postmodernism, or, the Cultural Logic of Late Capitalism, Verso, London-New York 1992.

Perelman Bob, Parataxis and Narrative. The New Sentence in Theory and Practice, "American Literature"1993, Vol. 65, No. 2, pp. 312-324.

Perloff Marjorie, Avant-Garde Community and the Individual Talent, http://marjorieperloff.com/ essays/avant-garde-community-and-the-individual-talent/ [accessed on: 15.12.2017].

Silliman Ron, The New Sentence, in: The New Sentence, Roof Books, New York 2003.

Święch Jerzy, Ważyk metafizyczny?, "Ruch Literacki” 2013, issue 1 (316), pp. 35-47.

Trotsky Leon, Literature and Revolution, trans. Rose Strunsky, https://www.marxists.org/archive/ trotsky/1924/lit_revo/ [accessed on: 15.12.2017].

Ważyk Adam, Amfion, Czytelnik, Warszawa 1983.

Ważyk Adam, Dziwna historia awangardy, Czytelnik, Warszawa 1976.

Ważyk Adam, Esej o wierszu, Czytelnik, Warszawa 1964.

Ważyk Adam, Eseje literackie, Państwowy Instytut Wydawniczy, Warszawa 1982.

Ważyk Adam, Obnażenie przypadku, "Teksty. Teoria literatury, krytyka, interpretacja” 1973, issue 3 (9), pp. 42-51.

\section{Paweł Kaczmarski}

\section{Adam Ważyk, poetyka 'New Sentence' i zagadnienie entropii}

\section{(Streszczenie)}

Punktem wyjścia artykułu jest omówienie roli, jaką w metapoetyckim i historycznoliterackim projekcie Adama Ważyka - jednego z najważniejszych praktyków i teoretyków polskiej awangardy poetyckiej - pełniła kategoria entropii. Refleksja nad entropią, luźno podbudowana nawiązaniami do nauk ścisłych, służyła Ważykowi do wyartykułowania stosunku do problemów formalnej organizacji wiersza: chociaż entropia, rozumiana w przypadku literatury jako ubytek informacji - zatarcie znaczenia - jest nieubłagana (i naiwnością byłoby próbować powstrzymać ją zupełnie), jej częściowe powściąganie pozostaje obowiązkiem twórcy i warunkiem jakiejkolwiek artystycznej komunikacji. Zarówno zupełne poddanie sile uniwersalnego rozproszenia, jak i próba otwartego jej zwalczenia skazane są na porażkę. 
W drugiej części artykułu to fundamentalne dla pism Ważyka napięcie połączone zostaje z szerszą debatą historycznie organizującą znaczną część teoretycznej refleksji dwudziestowiecznej lewicy; obserwacje Ważyka zestawione zostają ze sporem o parataksę, stoczonym na początku lat 90. przez amerykańskich poetów związanych z nurtem Language oraz Fredrika Jamesona, jednego z czołowych marksistowskich krytyków literackich. Napięcie między nieuchronnością a szkodliwością entropii, i wynikająca z niego konieczność formy, zostaje wskazane jako analogiczne do napięcia między nieuchronnością a szkodliwością rozproszenia (jako podstawy naraz ponowoczesnego doświadczenia i figury parataksy).

Słowa kluczowe: Adam Ważyk, poetyka, entropia, parataksa, poezja Language, postmodernizm, Fredrik Jameson, Ron Silliman.

\section{Paweł Kaczmarski}

\section{Adam Ważyk, the New Sentence and the question of entropy}

\section{(Summary)}

In its first section, the article focuses on certain concepts belonging to Adam Ważyk's theory of poetics. Specifically, I note the role of entropy in Ważyk's thought on the form of the poem. Ważyk's thinking of entropy served the poet to regulate his more general conception of the formal constitution of the poem. Although entropy seems to be an unavoidable process, the poet's role and duty is to partly control it. For Ważyk, such partial containment of entropy is the condition of poetic communication.

The second section of the article places the entropy-related tensions identified by Ważyk in the context of poetic debates of the 90's between Fredric Jameson, a prominent Marxist critic, and the American poets identified as the LANGUAGE group.

Keywords: Adam Ważyk, poetics, entropy, parataxis, Language poetry, postmodernism, Fredrik Jameson, Ron Silliman. 